\title{
The rediscovery of Pimelodella longipinnis (Borodin, 1927), an enigmatic Atlantic Rainforest catfish species from Southeastern Brazil (Siluriformes: Heptapteridae)
}

\author{
Veronica Slobodian ${ }^{1}$; Bruno Abreu-Santos ${ }^{2} \&$ Murilo Nogueira de Lima Pastana $^{3}$ \\ 1 Universidade de Brasília (UNB), Instituto de Ciências Biológicas (ICB), Departamento de Zoologia, Laboratório de Ictiologia Sistemática. \\ Brasilia, DF, Brasil. ORCID: http://orcid.org/0000-0002-4754-5871. E-mail: vslobodian@unb.br (corresponding author) \\ 2 Independent researcher. São Paulo, SP, Brasil. ORCID: http://orcid.org/0000-0002-9762-1369. E-mail: giga.abreu@gmail.com \\ 3 Smithsonian Institution, National Museum of Natural History (NMNH), Department of Vertebrate Zoology, Division of Fishes. \\ Washington, D.C., SC, United States. ORCID: http://orcid.org/0000-0003-3906-0863. E-mail: PastanaM@si.edu
}

\begin{abstract}
This article is a redescription of Pimelodella longipinnis, an enigmatic catfish previously known only from its holotype and with uncertain type locality. The species is redescribed based on recently collected materials from streams of the Mata Atlântica bioregion, in Santos municipality, São Paulo State, Brazil. Pimelodella longipinnis is assigned to a putatively monophyletic group, the Pimelodella leptosoma-group, diagnosed by the presence of a supraoccipital process not reaching the anterior nuchal plate, with a gap of ca. 20-25\% of the supraoccipital process total length, and whose tip notably surpasses the midpoint of the complex vertebra in dorsal view. We also present a list of fish species described from a shipping sent to the American Museum of Natural History from the former Museu Paulista (now Museu de Zoologia da Universidade de São Paulo), of which P. longipinnis was part.
\end{abstract}

Keywords. Mata Atlântica bioregion; Neotropical Ichthyology; Pimelodella leptosoma-group; Taxonomy.

\section{INTRODUCTION}

Pimelodella Eigenmann, 1888 is a genus of Neotropical catfish family Heptapteridae distributed throughout cis- and trans-Andean drainages. With 82 species currently considered valid (Fricke et al., 2021), a conservative morphology and putatively wide distributions, the genus currently represents one of the most difficult bottlenecks for understanding the diversity of Neotropical catfishes. In addition, Pimelodella still lacks comprehensive taxonomic or phylogenetic studies, which result in great difficulty in diagnosing several individuals found in scientific collections (Slobodian et al., 2017), even those collected in well-sampled locations.

Currently, the genus Pimelodella can only be diagnosed from other Heptapteridae by a unique character combination. These include small to medium-size catfishes, usually between 12 and $30 \mathrm{~cm}$ of standard length [although some species, e.g., Pimelodella cristata (Müller \& Troschel, 1849), may exceed $30 \mathrm{~cm}$ ]; supraoccipital process long, usually reaching the anterior nuchal plate; anterior and posterior fontanels open, elongated, separated by an epiphyseal bar; eyes well-delimited by a free orbital rim, especially pronounced anteriorly and dorsally; pectoral fins with one unbranched, rigid and pungent spinous ray at leading edge, bearing usually both anterior denticulations and posterior serrae, followed by 7-9 (usually 8 ) branched rays; branchiostegal rays usually 6 ; caudal fin deeply forked; median caudal-fin rays not articulated to hypural plates; hypural 5 autogenous, but contacting the hypural plate; body generally with a dark midlateral stripe extending from the snout or just posterior to the opercle to the insertion of, or onto, median caudal-fin rays (Slobodian et al., 2017).

Pimelodella species are distributed throughout the Central and South America, occurring in all the major basins, including the Amazonas, Orinoco, Paraná-Paraguay, São Francisco, and Atlantic Coastal drainages, with the Amazon basin harboring its highest diversity (Slobodian, 2017). The Mata Atlântica and Upper Paraná bioregions (sensu Dagosta et al., 2020) are among the most well-sampled and intensively studied Neotropical areas, which is possibly influenced by their proximity to large urban centers (Agostinho et al., 
2007; Dagosta et al., 2020). However, the closeness of these drainages to large metropolitan centers, such as São Paulo and Rio de Janeiro, has historically posed a series of risks to fishes inhabiting these areas. Currently, these taxa are among the most threatened due to habitat destruction, introduction of non-native species, pollution, among other anthropic deleterious activities (Agostinho et al., 2007; Silva et al., 2020).

Seventeen nominal species of Pimelodella are described from Mata Atlântica and Upper Paraná bioregions, namely: P. avanhandavae Eigenmann, 1917; P. bahiana (Castelnau, 1855); P. boschmai Van der Stigchel, 1964; P. brasiliensis (Steindachner, 1877); P. eigenmanni Boulenger, 1891; P. gracilis (Valenciennes, 1835); P. harttii (Steindachner, 1877); P. ignobilis (Steindachner, 1907); P. itapicuruensis Eigenmann, 1917; P. kronei (Miranda Ribeiro, 1907); P. lateristriga (Lichtenstein, 1823); P. Iongipinnis (Borodin, 1927a); P. meeki Eigenmann, 1910; P. pappenheimi Ahl, 1925; P. pectinifera Eigenmann \& Eigenmann, 1888; P. rudolphi Miranda Ribeiro, 1918; and P. transitoria Miranda Ribeiro, 1907. Among those, $P$. longipinnis deserves special attention due to its rather enigmatic identity and complex taxonomic history. This species was originally described as Rhamdella longipinnis by Borodin (1927a) based on a single specimen sent from Museu Paulista (now Museu de Zoologia da Universidade de São Paulo) to the American Museum of Natural History. The original description neither offered a precise designation of the type location (referred to as only "Prov. St. Paulo, ?, Brazil"; Borodin, 1927a) nor it justified the allocation of the new species in Rhamdella. It was just recently, upon examination of its type material, that Rhamdella longipinnis was transferred to Pimelodella (Bockmann \& Miquelarena, 2008), based on the presence of long maxillary barbels and a sharp, long supraoccipital process, that the authors described as contacting the prenuchal plate. However, the species remained known only from a single specimen (the holotype), of uncertain locality.

Recent ichthyological expeditions to the South Atlantic coastal streams in the State of São Paulo yielded a distinctive species of Pimelodella, which revealed to fit the diagnosis of Pimelodella longipinnis. This species was not included in previous reviews of South Atlantic coastal stream fishes (e.g., Guazzelli, 1997; Menezes et al., 2007), being this the first work to offer a more precise distribution range to $P$. longipinnis, as well as a redescription of the species.

\section{MATERIAL AND METHODS}

Measurements are point-to-point distances taken with a digital caliper under a dissecting scope, following Slobodian \& Pastana (2018). Body measurements are presented as proportions of Standard Length (SL) and head parts are presented as proportions of Head Length (HL) (except for measurements of barbels, which are offered as proportions of SL). Meristics and descriptions of fin position follow Bockmann \& Castro (2010). Vertebral counts include the Weberian complex elements counted as five, plus all free vertebrae and the compound caudal centrum (PU1+U1) counted as one (sensu Lundberg \& Baskin, 1969). Number of specimens with each meristic value is presented in parentheses, followed by an asterisk indicating values for the holotype when a range is presented.

Clearing and staining protocol follow Taylor \& Van Dyke (1985), with the prepared specimens indicated by "c\&s". Osteological data was also obtained with aid of $X$-ray images of the holotype and five comparative specimens, which are indicated by "xr". Osteological and cephalic laterosensory canals terminology follows primarily Bockmann \& Miquelarena (2008), with modifications proposed by Pastana et al. (2020). Nomenclature for pectoral-fin and dorsal-fin ornamentations follow Slobodian \& Pastana (2018), with modifications of Kubicek et al. (2019). Fading coloration marks on holotype were observed with the aid of an ultraviolet light lantern (NettoFerreira \& Luckenbill, 2017). Food preference was investigated using the stomach contents of six specimens, obtained by stomach dissection. In situ behavior was registered with a stationary camera Panasonic Lumix DMC-TS20 on three occasions, in four locations, during 15 minutes in the afternoon. Categorization of observed behavior follows Wilson \& Roys (1994) and Morgan \& Fine (2020).

Institutional abbreviations follow Sabaj (2020). Maps were produced using Google Earth Web and Quantum GIS 2.18, and edited in Adobe Photoshop CC 2019. Photos were edited in Adobe Photoshop CC 2019. Illustrations of pectoral-fin spines were produced with Adobe Illustrator CC 2019, based on photographs and direct observation. Specimens were preserved in $70 \%$ ethanol unless indicated as cleared and stained (c\&s), which are preserved in glycerol. Comparative material of Pimelodella species is as presented in Slobodian et al. (2017), with additional specimens listed in the "Comparative material" section.

\section{RESULTS}

A thorough revision of Pimelodella specimens from the main scientific collections in Brazil and abroad by the first author revealed the occurrence of an enigmatic Pimelodella species occurring in three collection sites from Rio Quilombo and Rio Jurubatuba (Santos municipality, São Paulo State, Brazil). Such specimens were not congruent neither with Pimelodella species previously attributed to the Mata Atlântica in recent reviews of the region (e.g., Menezes et al., 2007) nor with those reported on the unpublished dissertation on Pimelodella species from coastal rivers in Southern and Southeastern Brazil (Guazzelli, 1997).

Upon comparison with the types of Pimelodella species from Mata Atlântica and Upper Paraná bioregions, the recently collected material was found to be undistinguishable from Pimelodella longipinnis (Borodin, 1927a). Morphometric data from specimens from the Rio Quilombo and Rio Jurubatuba, altogether with other 
morphological characteristics (see below), are strikingly congruent with data collected from the holotype of P. longipinnis (AMNH 8642) (Table 1). These fishes share relatively short maxillary barbels, reaching between verticals through pelvic-fin origin and anal-fin terminus (38.9-64.6\% SL), dorsal-fin first branched ray somewhat short (10.6-22.5\% SL), and adipose-fin length three to four times in SL (14.6-34.8\% SL).

In addition, radiographs of the specimens examined from Rio Quilombo and Rio Jurubatuba reveal that their supraoccipital process do not reach the anterior prenuchal plate. Among the Pimelodella species from the Mata Atântica and Upper Paraná, this condition is shared only with $P$. itapicuruensis and $P$. longipinnis. Nevertheless, the type specimens of Pimelodella itapicuruensis (FMNH 57951, 57953, 57986, 57987, and 57988) have maxillary barbels usually surpassing anal-fin terminus $(65.3-87.5 \% \mathrm{SL})$, first dorsal-fin branched ray (the longest) $20.9-26.2 \% \mathrm{SL}$, and adipose-fin length roughly three times in SL (32.1-38.6\% SL), all characteristics that do not match the specimens from Rio Quilombo and Rio Jurubatuba. In fact, these characteristics are highlighted by Eigenmann (1917) as being diagnostic of P. itapicuruensis in its original description (Eigenmann, 1917: p. 247248, pl. XXXI, fig. 3).

Further evidence pointing that the material from from Rio Quilombo and Rio Jurubatuba represent Pimelodella longipinnis comes from its color pattern. When observed under ultraviolet light (following Netto-Ferreira \& Luckenbill, 2017), the holotype of $P$. longipinnis revealed to have some fading coloration marks, despite no marks being presented in the original description (Borodin, 1927a). This fish has a poorly-defined, dark brown midlateral stripe extending from orbit to caudal fin origin, altogether with a poorly-defined darker region near dorsal fin base. These marks match perfectly the color pattern observed in the specimens from Rio Quilombo and Rio Jurubatuba.

In sum, based on the strikingly morphological similarities between the holotype of $P$. longipinnis and the recently collected specimens from Rio Quilombo and Rio Jurubatuba, we conclude these last belong to $P$. longipinnis. Therefore, this species is redescribed herein in light of a detailed examination of the holotype and additional 63 recently-collected specimens. An updated geographic range is provided for Pimelodella longipinnis, which now includes South Atlantic coastal streams of the São Paulo State.

\section{Pimelodella longipinnis (Borodin, 1927) Figs. 1-4; Table 1}

\section{Synonymy}

Rhamdella longipinnis Borodin, 1927a: 6-7 (original description; "Prov. St. Paulo, ?, Brazil"; holotype: AMNH 8642). - Gosline, 1945: 35 (checklist of species). - Fowler, 1951: 565 (checklist of species). Burgess, 1989: 278 (checklist of species). - Bockmann
\& Guazzelli, 2003: 422 (checklist of species). - FerrarisJr., 2007: 196 (checklist of species). - Bockmann \& Miquelarena, 2008: 45-46, table 3 (taxonomic treatment, Rhamdella revision, transfer to Pimelodella). Oyakawa \& Menezes, 2011: 7 (checklist of species).

Pimelodella longipinnis. - Bockmann \& Miquelarena, 2008: Table 3 (taxonomic treatment, transfer to Pimelodella). - Slobodian et al., 2017: 96 (comparative material).

\section{Diagnosis}

Pimelodella longipinnis differs from all its congeners, except $P$. bockmanni Slobodian \& Pastana, 2018; P. itapicuruensis; P. leptosoma (Fowler, 1914); P. megalura Miranda Ribeiro, 1918; P. metae Eigenmann, 1917; P. montana Allen, 1942; P. peruensis Fowler, 1915, P. robinsoni, P. tapatapae Eigenmann, 1920, P. wolfi (Fowler, 1941) and P. yuncensis Steindachner, 1902, by having the supraoccipital process not reaching the anterior prenuchal plate (vs. supraoccipital process articulating with the anterior nuchal plate in all other Pimelodella species). From the remaining species, it differs from $P$. tapatapae by having the tip of the maxillary barbel reaching the region between verticals through pelvic-fin origin and anal-fin terminus ( $v s$. reaching the caudal-fin origin). It differs from P. bockmanni, P. itapicuruensis, P. leptosoma, P. megalura, $P$. metae, and $P$. robinsoni by having dark coloration on lateral and dorsal regions of body (vs. body coloration paler, sometimes slightly darker anterodorsally). It differs from P. montana by the absence of a paired dorsolateral stripe extending from supraoccipital process to anterior one third of adipose-fin base ( $v s$. a single dorsolateral stripe present). It is distinguished from $P$. peruensis and $P$. yuncensis by the dorsal fin presenting a hyaline stripe at the second fourth of dorsal-fin length, and maxillary barbel surpassing the vertical through pelvic-fin origin (vs. dorsal fin completely dark, without hyaline stripe; maxillary barbel very short, reaching the vertical up through half pectoral fin, but rarely surpassing the pelvic-fin origin).

When compared to Pimelodella species from the Mata Atlântica and Upper Paraná bioregions, Pimelodella longipinnis can be distinguished from $P$. avanhandavae, P. bahiana, P. boschmai, P. brasiliensis, P. eigenmanni, $P$. gracilis, $P$. harttii, P. ignobilis, $P$. kronei, P. lateristriga, P. meeki, P. pappenheimi, P. pectinifera, P. rudolphi, and $P$. transitoria by having the supraoccipital process not reaching the anterior prenuchal plate (vs. supraoccipital process articulating with the anterior nuchal plate in the mentioned Pimelodella species) and hypural 5 variably fused to hypurals $3+4$ (vs. hypural 5 never fused to hypurals $3+4)$. Pimelodella longipinnis can also be distinguished from $P$. gracilis by the maxillary barbels reaching between verticals through pelvic-fin origin and anal-fin terminus ( $v s$. maxillary barbels surpassing anal-fin terminus, usually reaching caudal-fin origin in $P$. gracilis) and by 41-42 total vertebrae (vs. 46 total vertebrae). It differs from $P$. avanhandavae, P. bahiana, P. brasiliensis, P. eigenmanni, P. harttii, P. ignobilis, P. kronei, P. lateristriga, P. pappenheimi, $P$. rudolphi, and $P$. transitoria by the dorsal-fin 
Table 1. Morphometric data for holotype and other 63 specimens of Pimelodella longipinnis. Abbreviations: Max = maximum; Min $=$ minimum; $\mathrm{n}=$ number of specimens; $S D=$ standard deviation; $x=$ average.

\begin{tabular}{|c|c|c|c|c|c|c|}
\hline & Holotype & Min & Max & $x$ & SD & $\mathbf{n}$ \\
\hline Total length (mm) & - & 31.1 & 90.6 & 61.4 & & 63 \\
\hline Standard length (mm) & 84.6 & 25.4 & 84.6 & 50.8 & & 64 \\
\hline \multicolumn{7}{|l|}{ Percentages of SL } \\
\hline Body depth (dorsal) & 13.9 & 13.9 & 19.6 & 17.2 & 1.2 & 64 \\
\hline Body width (dorsal) & 10.2 & 10.2 & 17.2 & 13.6 & 1.2 & 64 \\
\hline Cleithral width & 15.1 & 15.1 & 20.7 & 18.2 & 1.1 & 64 \\
\hline Head length & 24.0 & 17.0 & 34.6 & 27.5 & 3.2 & 64 \\
\hline Maxillary-barbel length (left side) & 64.6 & 38.9 & 64.6 & 46.6 & 4.4 & 58 \\
\hline Outer mental-barbel length (left side) & 20.8 & 11.1 & 23.1 & 17.5 & 2.7 & 64 \\
\hline Inner mental-barbel length (left side) & 12.0 & 5.3 & 13.0 & 10.3 & 1.6 & 64 \\
\hline Predorsal length & 28.1 & 28.1 & 39.4 & 34.9 & 2.2 & 64 \\
\hline Distance between snout tip and terminus of dorsal-fin base & 42.3 & 42.3 & 52.6 & 48.6 & 1.6 & 64 \\
\hline Distance between snout tip and dorsal-fin distal end & 52.5 & 52.5 & 63.6 & 58.9 & 2.1 & 64 \\
\hline Dorsal fin to adipose fin & 13.2 & 9.9 & 21.1 & 16.0 & 2.4 & 64 \\
\hline Dorsal-fin base & 15.1 & 10.7 & 21.6 & 14.4 & 1.6 & 64 \\
\hline Length of first dorsal-fin ray (unbranched) & 16.5 & 12.1 & 24.8 & 17.2 & 2.2 & 60 \\
\hline Length of rigid part of first dorsal-fin ray & 9.2 & 9.0 & 20.3 & 12.5 & 1.8 & 63 \\
\hline Length of second dorsal-fin ray (first branched) & 22.3 & 10.6 & 22.5 & 17.9 & 2.1 & 64 \\
\hline Length of third dorsal-fin ray (second branched) & - & 11.2 & 21.3 & 17.3 & 2.0 & 63 \\
\hline Prepectoral length & 16.9 & 16.9 & 31.4 & 24.0 & 2.0 & 64 \\
\hline Distance between snout tip and terminus of pectoral-fin base & 20.3 & 20.3 & 34.6 & 28.0 & 2.0 & 64 \\
\hline Distance between snout tip and pectoral-fin distal end & 33.4 & 28.1 & 46.5 & 41.5 & 3.5 & 63 \\
\hline Length of first left pectoral-fin ray (unbranched) & 16.2 & 7.4 & 40.8 & 17.6 & 4.0 & 63 \\
\hline Length of rigid part of first left pectoral-fin ray & 13.6 & 7.4 & 24.2 & 14.4 & 2.1 & 64 \\
\hline Length of second left pectoral-fin ray (first branched) & 15.6 & 4.6 & 30.1 & 16.4 & 3.0 & 64 \\
\hline Length of third left pectoral-fin ray (second branched) & 14.7 & 10.4 & 28.0 & 15.3 & 2.5 & 64 \\
\hline Prepelvic length & 38.9 & 38.9 & 50.8 & 47.3 & 1.8 & 64 \\
\hline Distance between snout tip and terminus of pelvic-fin base & 40.8 & 34.2 & 55.1 & 50.6 & 2.9 & 64 \\
\hline Distance between snout tip and pelvic-fin distal end & 55.4 & 44.4 & 69.0 & 62.8 & 3.2 & 64 \\
\hline Distance between pelvic fins & 3.8 & 2.6 & 50.1 & 4.9 & 5.8 & 64 \\
\hline Length of first left pelvic-fin ray (unbranched) & 10.8 & 8.0 & 16.1 & 12.4 & 1.8 & 64 \\
\hline Length of second left pelvic-fin ray (first branched) & 14.0 & 8.6 & 17.5 & 13.5 & 1.6 & 64 \\
\hline Length of third left pelvic-fin ray (second branched) & 14.2 & 9.2 & 17.5 & 13.7 & 1.6 & 64 \\
\hline Anal-fin base & 15.5 & 10.9 & 17.5 & 14.3 & 1.5 & 64 \\
\hline Preanal length & 64.4 & 62.3 & 70.6 & 67.1 & 1.8 & 64 \\
\hline Distance between snout tip and terminus of anal-fin base & 78.5 & 77.3 & 85.7 & 81.3 & 1.7 & 64 \\
\hline Distance between snout tip and anal-fin distal end & 88.2 & 84.4 & 94.4 & 88.2 & 1.8 & 64 \\
\hline Adipose-fin length & 34.8 & 14.6 & 34.8 & 23.5 & 2.9 & 64 \\
\hline Preadipose length & 54.6 & 54.6 & 71.9 & 65.4 & 2.6 & 64 \\
\hline Distance between snout tip and adipose-fin base end & 88.9 & 83.9 & 95.0 & 88.4 & 1.7 & 64 \\
\hline Adipose-fin depth & 3.7 & 2.4 & 26.4 & 4.9 & 2.9 & 64 \\
\hline Caudal-peduncle length posterior to adipose-fin & 10.7 & 8.5 & 25.2 & 13.0 & 2.6 & 63 \\
\hline Caudal-peduncle depth at adipose-fin terminus & 7.1 & 6.2 & 10.9 & 8.0 & 0.9 & 63 \\
\hline Snout-anus distance & 44.6 & 44.6 & 60.0 & 54.4 & 2.3 & 64 \\
\hline Snout-urogenital papilla distance & 49.9 & 49.9 & 62.0 & 57.3 & 2.0 & 63 \\
\hline Anus-urogenital papilla distance & 5.4 & 0.6 & 5.4 & 2.5 & 0.9 & 62 \\
\hline Dorsal lobe of caudal fin length & - & 18.8 & 26.7 & 22.6 & 1.6 & 61 \\
\hline Ventral lobe of caudal fin length & - & 17.4 & 24.6 & 21.5 & 1.7 & 62 \\
\hline \multicolumn{7}{|l|}{ Percentages of $\mathrm{HL}$} \\
\hline Head depth & 53.7 & 40.4 & 69.4 & 51.2 & 6.2 & 61 \\
\hline Head width & 61.7 & 49.8 & 80.7 & 64.4 & 6.0 & 60 \\
\hline Eye diameter (left) & 20.3 & 13.3 & 36.2 & 20.3 & 3.9 & 64 \\
\hline Fleshy interorbital & 20.7 & 18.8 & 47.8 & 28.0 & 5.8 & 64 \\
\hline Bony interorbital & 16.9 & 11.1 & 30.5 & 17.4 & 3.1 & 63 \\
\hline Mouth gape & 30.6 & 15.6 & 57.1 & 40.0 & 6.1 & 64 \\
\hline Snout length (left) & 30.7 & 30.5 & 67.6 & 38.0 & 5.5 & 64 \\
\hline Distance between snout tip and posterior nare (left side) & 19.5 & 16.8 & 41.1 & 24.3 & 4.5 & 64 \\
\hline Anterior internarial width & 14.2 & 7.1 & 28.5 & 16.5 & 3.3 & 64 \\
\hline Posterior internarial width & 15.1 & 12.3 & 31.3 & 17.2 & 3.1 & 64 \\
\hline Intranarial length (left side) & 13.2 & 10.6 & 25.8 & 16.4 & 2.9 & 64 \\
\hline
\end{tabular}


spine being approximately half to two-thirds of first dorsal-fin ray total length (vs. dorsal-fin spine roughly threefourths of first dorsal-fin ray total length). It also differs from $P$. avanhandavae, P. gracilis, and P. itapicuruensis by the short adipose fin, three to four times in SL (vs. two and half to three times in SL in $P$. avanhandavae and $P$. itapicuruensis; two to two and half times in SL in P. gracilis). Pimelodella longipinnis further differs from all Mata Atlântica and Upper Paraná species by having an overall dark body coloration, with purplish hue in life, with dark brown midlateral stripe narrow, extending from posterior portion of orbit to caudal-fin origin.

\section{Description}

Morphometric data in Table 1. Body depressed, depth at dorsal-fin origin five to seven times in SL and compressed, body width at dorsal-fin origin seven to ten times in SL (Fig. 1). Greatest body depth at dorsal-fin origin. Dorsal body profile convex from snout to origin of dorsal fin, slightly concave from that point to origin of adipose fin, convex along base of adipose fin, and concave along caudal peduncle. Ventral profile of body slightly convex from snout to branchiostegal membrane, then again convex in separate arc between branchiostegal membrane and pectoral-fin, convex between pectoral end pelvic fins, slightly convex from pelvic to anal fin, and concave from that point to caudal-fin origin.

Head moderately deep, head depth (at base of supraoccipital process) $1 / 2$ to $2 / 3$ of head length. Mouth subterminal. Eye elliptical, its longest diameter four to seven times in head. Bony interorbital distance slightly lesser than eye diameter. Barbels thin, slightly compressed, and elliptical in cross-section. Maxillary barbel when parallel to main body axis reaching to vertical through area between pelvic-fin origin and anal-fin terminus. Outer mental barbel when parallel to main body axis, reaching to verticals through area between origin and distal third of adpressed pectoral-fin. Inner mental barbel, when parallel to main body axis, reaching to verticals through area between posterior ventral limit of branchiostegal membrane and pectoral-fin origin. Supraoccipital process narrow, roughly rectangular, contacting the dorsal lamina of Weberian complex only at anterior tip. Branchiostegal rays 6 (49). Pseudotympanum large, oval, dorsal to posterior process of cleithrum and posteriorly reaching $6^{\text {th }}(2)$ or $7^{\text {th }}\left(2^{*}\right)$ vertebra. Posterior process of cleithrum triangular, narrow, with straight dorsal margin. Anus and urogenital papilla adjacent. Urogenital papilla short, tubular and somewhat triangular. Anus roughly positioned at vertical through first third of adpressed pelvic fin; urogenital papilla near vertical through second third of adpressed pelvic fin.

Dorsal fin triangular, with concave distal margin. Longest dorsal-fin ray length four to six times in $\mathrm{SL}$, its depressed tip reaching verticals through half or last fourth of adpressed pelvic-fin. Dorsal fin 1,6 (49) plus anterior spinelet. Distance between terminus of dorsal-fin base and adipose-fin origin roughly equal to dorsal-fin base. First dorsal-fin pterygiophore inserted posterior to neural spine of vertebrae 5 (5); last dorsal-fin pterygiophore located posterior to neural (or pseudoneural) spine of vertebrae 10 (5). Unbranched dorsal-fin ray spinous for ca. $50-70 \%$ of its length, distal portion filamentous. No ornamentations on anterior or posterior margins of dorsal-fin spine. Pectoral-fin rays I,7 (5) or I,8* (45), pectoral fin

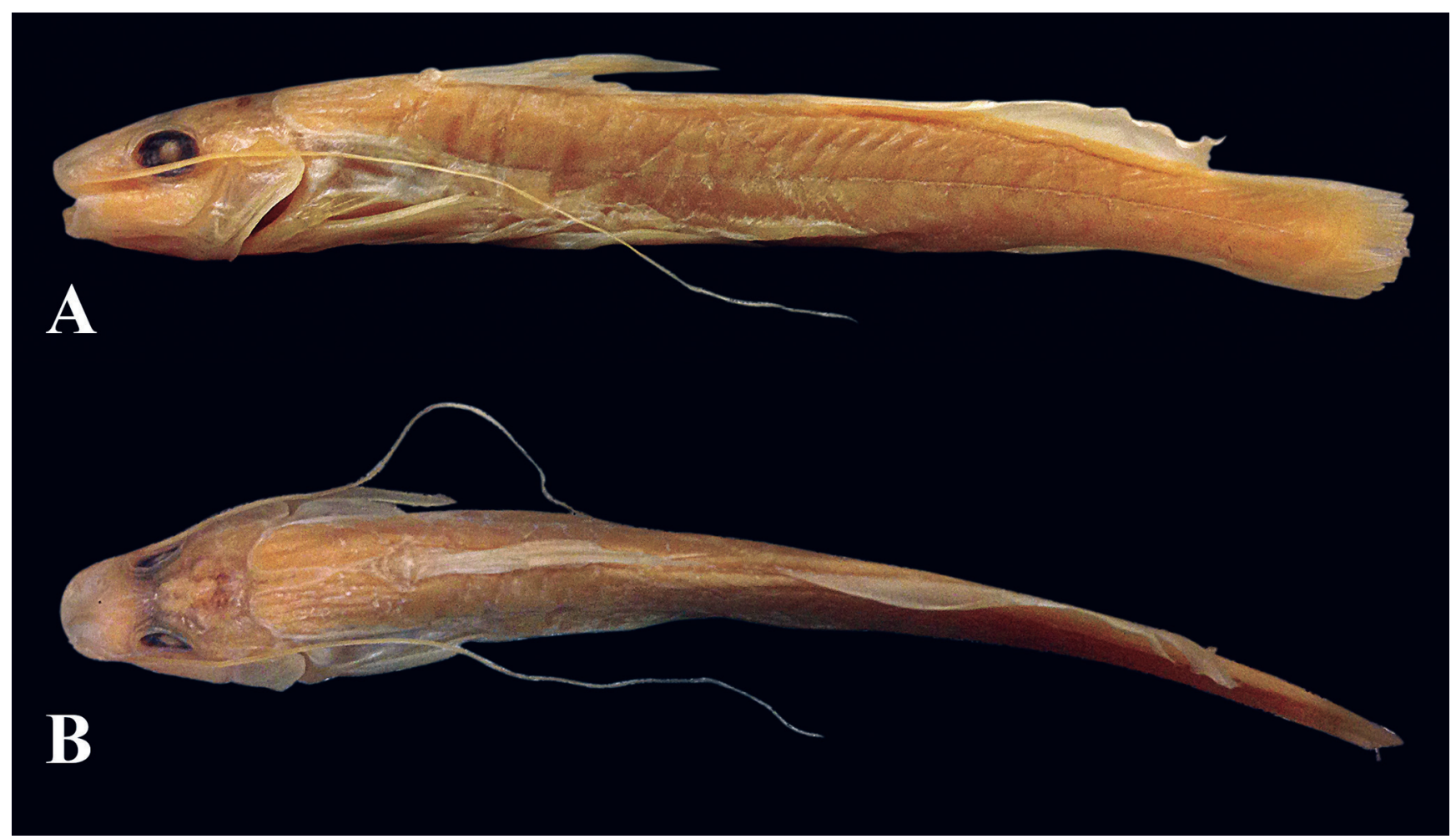

Figure 1. Left lateral (A) and dorsal (B) views of Pimelodella longipinnis (Borodin, 1927), AMNH 8642, holotype of Rhamdella longipinnis, 84.6 mm SL. Photo provided by AMNH staff. 


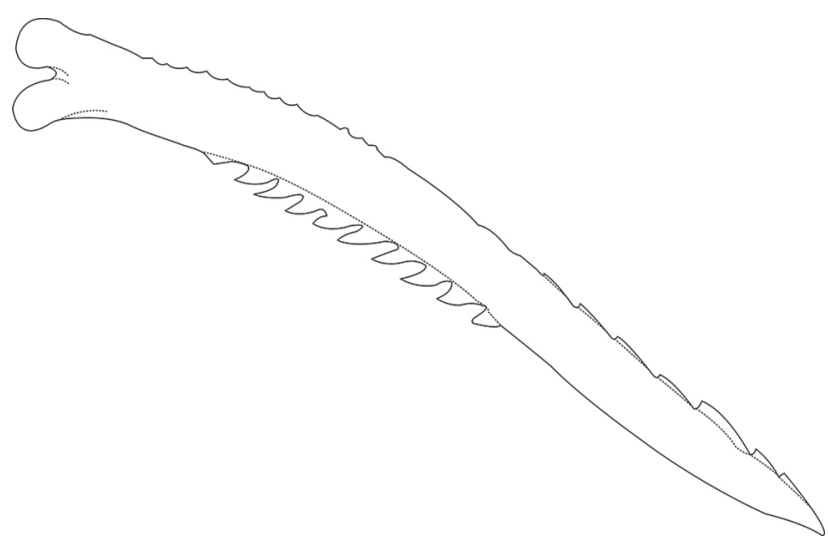

Figure 2. Ventral view of left pectoral-fin spine of Pimelodella longipinnis, AMNH 8642, holotype of Rhamdella longipinnis, total length of spine $11.5 \mathrm{~mm}$.

triangular, margin concave. First pectoral-fin ray roughly straight with proximal part rigid, forming spine (Fig. 2), short distal tip flexible and segmented, corresponding to the unossified actinotrichia bundle. Anterior margin of pectoral-fin spine with smooth serrae along its distal third, and minute denticulations along its proximal half to two-thirds (denticulations progressively more spaced distally); posterior margin with 8-10 straight to retrorse serrae along its basal two-thirds. Distalmost posterior serrae larger and more curved than 2-3 basal ones. One or two additional unossified distal serrae present (not included in counts). Pelvic-fin rays i,5 (50), expanded pelvic fin triangular with straight distal border. Pelvic-fin origin at vertical through terminus of dorsal-fin base. Tip of adpressed pelvic fin at vertical through origin of adipose fin. First unbranched ray not spinous, distinctly shorter than second and third ones; third ray longest, slightly longer than second one; remaining rays progressively shorter. Anal-fin ray formula variable, ii,8 (1); iii,8 (3); iv,8 (2); iii,9 (11); iv,9 (12*); iii,10 (4); iv, 10 (1); v,10 (2) or iii, 11 (2). One to three additional anterior accessory analfin rays present, embedded in thick integument, and not included in anal-fin ray count. Anal-fin distal margin convex when expanded. Anal fin origin at vertical through first third of adipose-fin base; adpressed anal-fin terminus between verticals through adipose-fin terminus or a point slightly anterior to that. First anal-fin pterygiophore posterior to haemal spine of vertebrae 20 (1), 21 (4) or $22^{*}(1)$. Last anal-fin pterygiophore posterior to haemal spine of vertebrae 27 (1), 28 (3), 29 (1) or 30* (1). Adipose fin short, three to six times in SL, forming ascending curve in lateral profile, with deepest point approximately at midlength. Adipose fin emerging gradually, its posterior limit forming round free lobe. Adipose-fin origin at vertical through vertebral centra $20 *(2), 22$ (2) or 23 (1); fin terminus at vertical through vertebral centra 35 (3), 36 (1) or $37^{*}(1)$. Caudal fin deeply forked, lobes equal in length or with dorsal one slightly longer. Caudal-fin dorsal lobe with 11 (1)-17 (1) (holotype 13) procurrent fin rays, followed by 1 (50) unbranched and 7 (50) branched principal fin rays. Ventral lobe with 11 (1)-19 (1) (holotype 14) procurrent fin rays, followed by 1 (50) unbranched and $8^{*}(48)$ or 9 (2) branched principal fin rays.

Hypural 5 free (3) or fused* (2) to complex plate formed by co-ossified hypurals 3 and 4 . Median caudal-fin rays not articulating directly with hypural plate. Seven (6) rays articulating with dorsal caudal-fin plate (5 on hypurals $3+4$ and 2 on hypural 5) and 7 (2) or $8^{*}(4)$ rays articulating with ventral caudal-fin plate (5 or 6 on hypurals $1+2$ and 2 on parhypural). Total vertebrae 41 (3) or 42* (4). Ribs 8* (1)-10 (1), usually 9 (5).

Epiphyseal branch of cephalic laterosensory canal (S6) emerging onto skin as two narrowly distanced pores* (46) or, less frequently, as a unique pore (S6+S6) (7).

\section{Coloration in alcohol}

Background body coloration mostly brown, ranging from dark brown dorsally to light brown or yellowish on ventral region of head and body (Fig. 3). Overall head coloration medium brown, with visible dark grey pigment along posterior fontanel, corresponding to a sheet of pigment covering the brain at this region. Dorsal region of maxillary barbel covered with dark brown to gray chromatophores. Outer and inner mental barbels hyaline. A poorly-defined, narrow, dark brown to dark gray midlateral stripe extending from orbit to caudal fin origin, where it broadens, and continues at median caudal-fin rays (Fig. 3). Poorly-defined darker region near dorsal fin base, varying from dark brown to dark gray coloration. Poorly-defined dark brown to dark gray col-

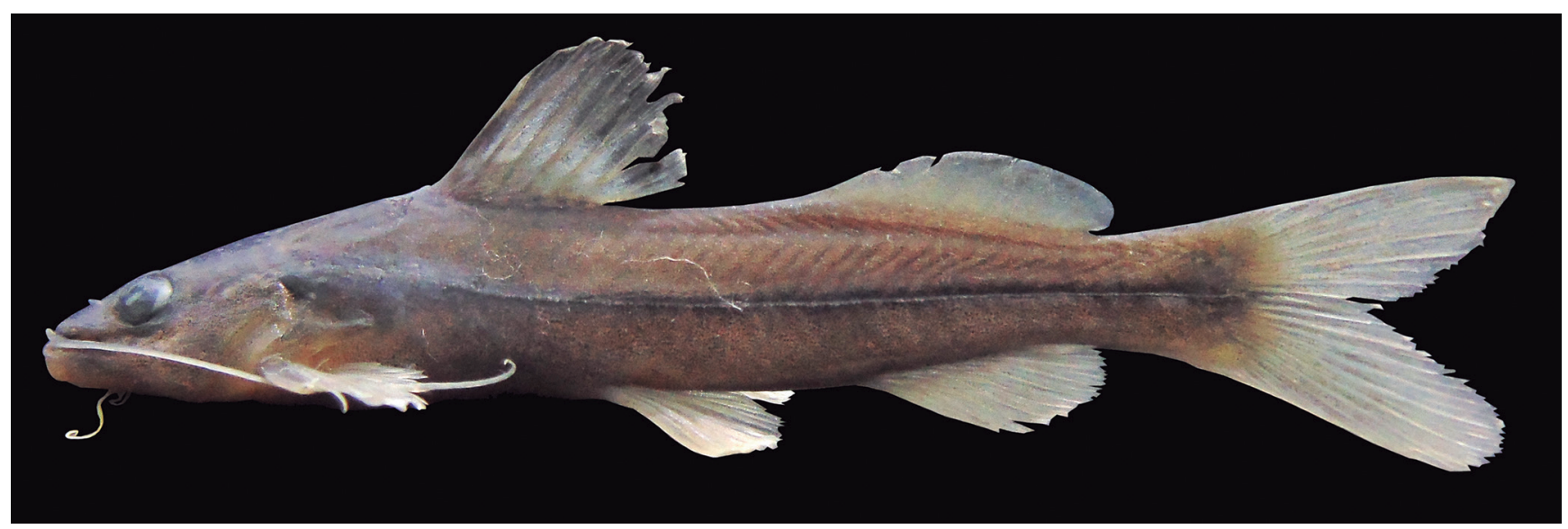

Figure 3. Left lateral view of an ethanol-preserved, recently collected specimen of P. Iongipinnis, MZUSP 116324, $57.6 \mathrm{~mm} \mathrm{SL.}$ 
oration at lateroventral region of body, posterior to vertical through cleithrum process and reaching pelvic-fin origin, fading dorsally near midlateral stripe. Additional dark grayish area at pseudotympanum region, exhibiting denser concentration of chromatophores, merging with midlateral stripe. Dorsal fin dark gray, with hyaline stripe near fin base, starting roughly from the first branchedray. Pectoral, pelvic, anal and caudal fins with scattered dark brown chromatophores along rays, and membrane between rays mostly hyaline.

\section{Coloration in life}

Background body coloration dark grey to purple (Fig. 4). Some specimens are slightly lighter, presenting a medium grey background body coloration. Ventral region of head and body cream colored, except at pectoral and pelvic-fin insertions, and near mental barbels insertions, that present scattered grey chromatophores. All dark brown/gray marks observed in alcohol specimens are also observable in life: midlateral stripe (and darker area at the pseudotympanum), along posterior fontanel, near dorsal-fin base, between cleithrum process and pelvic-fin origin, and along dorsal fin (except by the hyaline stripe). Dark grayish area at pseudotympanum slightly lighter in life than in ethanol-preserved specimens.

\section{Geographical distribution}

Pimelodella longipinnis is known to occur in South Atlantic coastal streams (= Mata Atlântica bioregion sensu Dagosta et al., 2020). Analyzed material are from Rio Quilombo and Rio Jurubatuba (Fig. 5), Santos, São Paulo State, Brazil.

\section{Ecological notes}

In both localities, P. longipinnis was collected in clear water, shallow streams, near sandy and rocky bottoms, with scattered leaf litter (Fig. 6), and also at water column. Collecting tools involved electric fishing and dipnet. Specimens were found in schools with five to 20 specimens, hiding at rocky crevices. Gut contents revealed an omnivore diet, with Trichoptera (80\%), shrimps (15\%), tadpoles (3\%), and unidentified plant material (2\%).

Subaquatic observations (Supplementary Material S1) revealed conspecific agonistic behaviors between $P$. Iongipinnis individuals. The observed behaviors are according to the following categories described for the channel catfish Ictalurus punctatus (Ictaluridae) (Wilson \& Roys, 1994): head thrust (abrupt swing of head, laterally, against other fish), head wag (series of head thrusts), tail beat (tail thrusts as a means of displacement another fish), and tail thrust (powerful lateral swing of the tail). Furthermore, a pectoral brush (pectoral-fin brush along the side of the opponent, either parallel or antiparallel), behavior described for the blue catfish Ictalurus furcatus (Ictaluridae) (Morgan \& Fine, 2020) was also observed. Described behaviors are probably related to territory dispute (Wilson \& Roys, 1994) and can be observed in the video provided in the Supplementary material.

\section{Conservation status}

Pimelodella longipinnis is so far known only from Southeastern Mata Atlântica streams at the estuarine region of Santos municipality. Both Rio Quilombo and Rio Jurubatuba have stretches protected by a Brazilian park, the Parque Estadual da Serra do Mar (PESM) (Fig. 5), which is the largest Protected Area of Mata Atlântica rainforest, with 332 hectares, covering 25 municipalities from São Paulo and Rio de Janeiro States (Fundação Florestal, 2021). Despite collections inside PESM have not been authorized, we believe that $P$. longipinnis distribution might include protected areas inside the PESM. Therefore, P. longipinnis is categorized herein as Least Concern (LC) according to the International Union for Conservation of Nature criteria (IUCN, 2012).



Figure 4. Live specimens of $P$. longipinnis, showing the coloration in life (preserved in MZUSP 116324). 


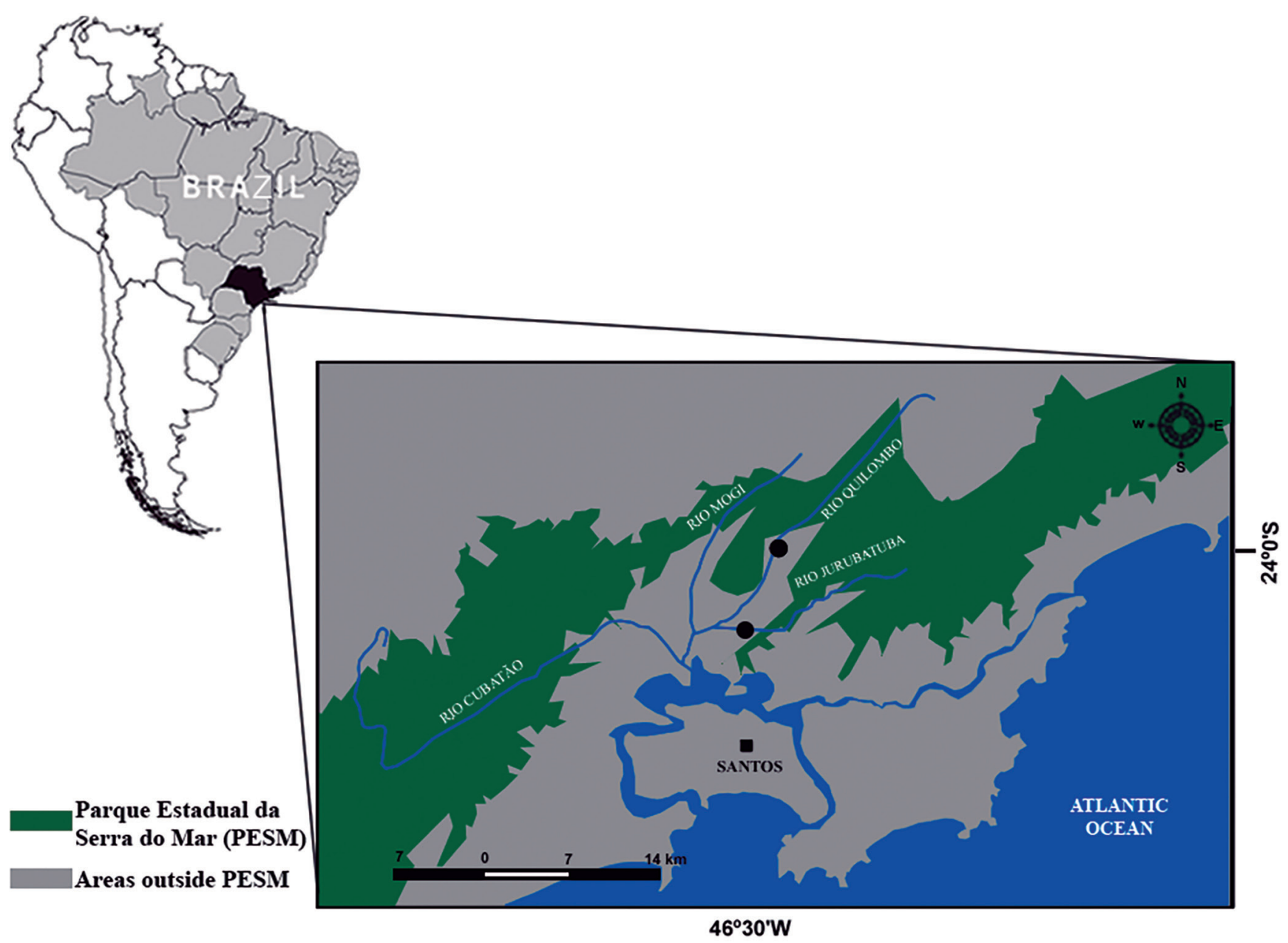

Figure 5. Distribution of Pimelodella longipinnis in Southeastern coastal Mata Atlântica streams of São Paulo State. In green is demarked part of the Parque Estadual da Serra do Mar extension. The collection sites are indicated by a black dot. The dot may correspond to more than one collection site. The center of Santos municipality is indicated by a black square.

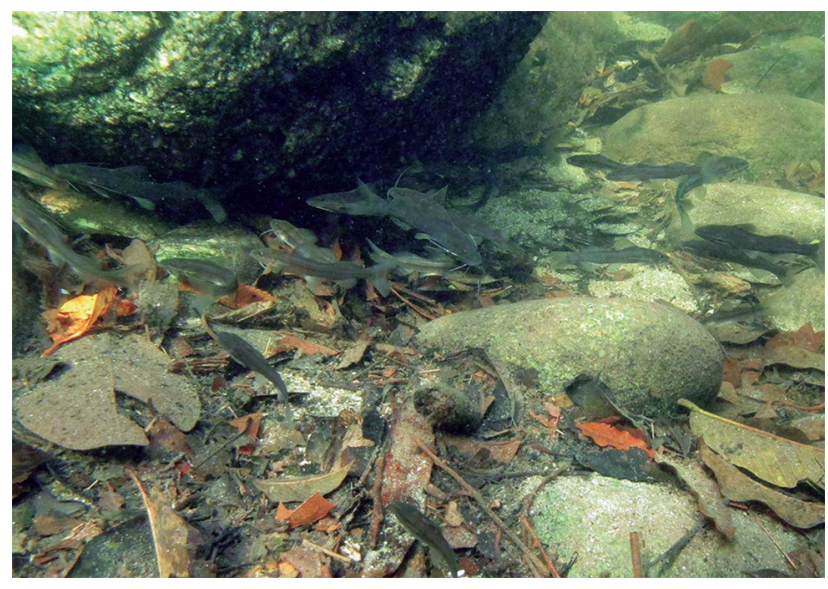

Figure 6. Subaquatic photograph at Rio Quilombo, a rocky bottom stream where part of $P$. longipinnis specimens were collected (MZUSP 116324). Photograph by Douglas Rey, December 2, 2014.

\section{Material observed}

Pimelodella longipinnis: AMNH 8642, 1 ex, $\mathrm{xr}$, 84.6 mm SL, holotype, Brazil, São Paulo; MZUSP 116324, 56 ex (4 xr), 2 c\&s, 25.4-84.6 mm SL, Brazil, São Paulo State, Santos municipality, river at km 136 of SP-56 highway

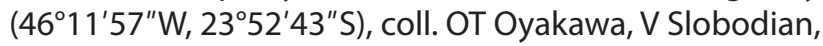

MCC Pinna, JAP Santos, B Abreu-Santos, 02 jun 2014; LIRP 10570, 5 ex (1 xr), 56.1-68.9 mm SL, Brazil, São Paulo State, Santos municipality, Rio Quilombo (46 $18^{\prime} 48^{\prime \prime} \mathrm{W}$, $\left.23^{\circ} 49^{\prime} 00^{\prime \prime} \mathrm{S}\right)$, coll. DD Figueiredo, B Abreu-Santos, 13 jan 2013; UNIFESP uncat., 1 ex, 84.5 mm SL, Brazil, São Paulo State, Santos municipality, Rio Jurubatuba $\left(46^{\circ} 17^{\prime} 12.1^{\prime \prime} \mathrm{W}, 23^{\circ} 51^{\prime} 31.5^{\prime \prime} \mathrm{S}\right)$, col. GT Vilara, February, 2018.

\section{DISCUSSION}

\section{Taxonomic considerations}

Pimelodella is certainly one of the most daunting taxonomic bottlenecks in Neotropical fishes. After Eigenmann (1917) revision, few species of Pimelodella have been subject to rigorous taxonomic studies (e.g., Mees, 1983; Leiva C., 2005; Souza-Shibatta et al., 2013; Slobodian et al., 2017; Slobodian \& Pastana, 2018; CondeSaldaña et al., 2019; Cortés-Hernández et al., 2020), in such a way that most species of the genus still await proper taxonomic and geographic delimitation.

A complete revision of Pimelodella species by Slobodian and de Pinna (in prep.) in underway, as well 
as a phylogenetic study of the relationships of its species (Slobodian et al., in prep.). In this present context of limited taxonomic and phylogenetic knowledge about Pimelodella, the recognition of putatively monophyletic subsets within the genus has proven to be a useful approach to describe new species (cf., Slobodian et al., 2017; Slobodian \& Pastana, 2018). Despite most Pimelodella species present a long supraoccipital process (i.e., reaching the anterior nuchal plate), some species present a slightly shorter supraoccipital process that never reaches the nuchal plate. Slobodian \& Pastana (2018) presented a list of eleven Pimelodella species bearing this condition (the Pimelodella leptosoma-group), which includes P. Iongipinnis. These species exhibit a gap between the tip of the supraoccipital process and the anterior nuchal plate, corresponding to ca. $20-25 \%$ of the supraoccipital process total length, whose tip notably surpasses the midpoint of the complex vertebra in dorsal view (Slobodian \& Pastana, 2018). This mentioned gap is significantly shorter than that one found in Rhamdella species (e.g., Bockmann \& Miquelarena, 2008: fig. 7), whose tip of the supraoccipital process does not reach the midpoint of the complex vertebra in dorsal view. Also, the distalmost portion of the supraoccipital process of Pimelodella leptosoma-group species is embedded in skin and connective tissue, what makes its length accurately determined only through dissection or with $x$-ray images. Those might be the reasons that made Bockmann \& Miquelarena (2008: p. 46) suggest that $P$. longipinnis has a "sharp long supraoccipital process that contacts the predorsal plate", altogether the authors affirmation that further discrimination of different states for this feature (their Character 8) was not pertinent to that study, focused on Rhamdella species.

Therefore, despite we disagree with Bockmann \& Miquelarena's (2008) assumption that $P$. longipinnis supraoccipital process "contacts the predorsal plate", we agree the condition found in P. longipinnis is different from those found in Rhamdella species. Additional discussion on such matters can be found in Slobodian \& Pastana (2018). It is worth mentioning that a recently published work on Heptapteridae relationships using molecular data (Silva et al., 2021) recovered Pimelodella as a polyphyletic genus of the subfamily Rhamdiinae. However, the authors did not include species of Rhamdella neither Pimelodella leptosoma-group in their analysis. Therefore, the evolution of the supraoccipital process in members of Rhamdiinae still awaits investigation under a phylogenetic approach.

Based on comparisons of the holotype of Rhamdella longipinnis with recently collected material from coastal streams of Southeastern Brazil, we could redescribe this species. Despite $P$. longipinnis locality being uncertain in its description, referred to as "São Paulo prov?", the presence of this species in Mata Atlântica streams is congruent with other species from the same shipping sent to the American Museum of Natural History from the former Museu Paulista (now Museu de Zoologia da Universidade de São Paulo), later described by Nichols (1919a, b) and Borodin (1927a, b, c). Among the materials sent to AMNH are individuals of Kronichthys lacerta (Nichols, 1919b) and Chasmocranus truncatorostris Borodin, 1927a, from the Mata Atlântica bioregion in São Paulo and Santa Catarina States, respectively; Hypostomus brevis (Nichols, 1919b) and Caecorhamdella brasiliensis Borodin 1927b (junior-synonym of Pimelodella kronei), generically described from "São Paulo", but now known to occur in the Upper Paraná ecoregion (Y, Figueiredo, pers. comm.) and Mata Atlântica bioregion (Ribeira de Iguape basin), respectively; besides several other species from Upper Paraná, São Francisco and Paraguay ecoregions. A summary of the species described from the shipping sent to AMNH from the former Museu Paulista are presented in Table 2.

As demonstrated in Table 2, the species described by Nichols (1919a, b) and Borodin (1927a, b, c) are from several collection events, most of them in São Paulo State, in Upper Paraná and Mata Atlântica locations. Whenever specific localities are presented for the types, collections occurred between 1898 and 1910 by several collectors, such as W. Ehrhardt, E. Garbe, R. von Ihering, $\mathrm{H}$. Luederwaldt and A. Oliveira (Nichols, 1919a, b; Borodin, $1927 \mathrm{a}, \mathrm{b}, \mathrm{c})$. However, generically defined localities are not accompanied from collectors' identification, what makes impossible the further investigation of the localities, trying to exactly pinpoint the collection sites.

Furthermore, among Pimelodella species from Mata Atlântica and Upper Paraná (the two bioregions that occur in São Paulo State, the uncertain type locality of $P$. longipinnis), only two species have the supraoccipital process almost reaching the anterior nuchal plate: $P$. itapicuruensis and $P$. longipinnis, and our recently collected material was identified as P. longipinnis due to the striking similarity with the holotype of this species. On the other hand, P. itapicuruensis, described from Rio Itapicuru, Bahia State, has longer maxillary barbels (65.3-87.5\% SL), reaching between verticals through anal-fin origin and terminus; pectoral-fin spine bearing at posterior margin 5-7 small, shallow, retrorse serrae along basal half (Slobodian et al., 2017: fig. 6B); and a dark brown midlateral stripe running from snout to median caudal-fin rays. Pimelodella longipinnis differs from $P$. itapicuruensis by having shorter maxillary barbels (38.9-64.6\% SL), reaching to area between verticals through pelvic-fin origin and anal-fin terminus; posterior margin of pectoral-fin spine with 8-10 straight to retrorse serrae along its basal two-thirds, larger than the ones found in P. itapicuruensis (Fig. 2); and dark grey midlateral stripe running from region posterior to orbit to caudal-fin origin, where it broadens, and continuing to median caudal-fin rays extension (Figs. 3, 4).

Besides $P$. longipinnis and P. itapicuruensis, other Pimelodella species that occur in Mata Atlântica bioregion are: $P$. bahiana, from Bahia State; $P$. brasiliensis, from São Paulo and Bahia States; P. eigenmanni, from São Paulo State; P. harttii from São Paulo and Rio de Janeiro States; P. ignobilis from Paraná and Santa Catarina States; P. lateristriga from São Paulo, Rio de Janeiro, Minas Gerais and Espírito Santos States; P. pappenheimi from Santa Catarina State; and P. pectinifera from Rio de Janeiro State. 
Table 2. Summary of species described by Nichols and Borodin based on shipping sent to the American Museum of Natural History from the former Museu Paulista (now Museu de Zoologia da Universidade de São Paulo). Species are followed by type locality (with bioregion indication whenever available, following Dagosta et al., 2020) and other taxonomic observations.

\begin{tabular}{|c|c|c|c|c|c|}
\hline Described as & $\begin{array}{c}\text { Type locality (and corresponding } \\
\text { bioregion sensu Dagosta et al., 2020) }\end{array}$ & Authority & Current status & $\begin{array}{l}\text { Transferred to current } \\
\text { status by }\end{array}$ & Observations \\
\hline Pseudotocinclus intermedius & $\begin{array}{l}\text { Campo Grande, near São Paulo } \\
\text { municipality (Upper Paraná bioregion) }\end{array}$ & Nichols, 1919a & $\begin{array}{l}\text { Pseudotocinclus tietensis } \\
\text { (Ihering, 1907) }\end{array}$ & Britski \& Garavello (1984) & \\
\hline Plecostomus brevis & uncertain at São Paulo State & Nichols, 1919b & $\begin{array}{l}\text { Hypostomus brevis } \\
\text { (Nichols, 1919b) }\end{array}$ & Isbrücker, 1980 & $\begin{array}{l}\text { probably occurs in Upper Paraná Streams } \\
\text { (Y. Figueiredo, pers. comm.) }\end{array}$ \\
\hline Plecostomus lacerta & $\begin{array}{l}\text { Poço grande, Rio Juquiá, São Paulo State } \\
\text { (Matla Atlântica bioregion) }\end{array}$ & Nichols, 1919b & Kronichthys lacerta & Burgess \& Finley (1996) & \\
\hline Plecostomus scaplyceps & $\begin{array}{l}\text { Cerqueira Cesar, São Paulo State (Upper } \\
\text { Paraná bioregion) }\end{array}$ & Nichols, 1919b & $\begin{array}{l}\text { Hypostomus albupunctatus } \\
\text { (Regan, 1908) }\end{array}$ & Zawadzki et al. (2019) & spelled as scaphyceps in English version \\
\hline Pseudopimelodus roosevelti & $\begin{array}{l}\text { Pirassununga municipality, São Paulo } \\
\text { State (Upper Paraná biorregion) }\end{array}$ & Borodin, 1927a & $\begin{array}{l}\text { Pseudopimelodus mangurus } \\
\text { (Valenciennes, 1835) }\end{array}$ & Shibatta (2003) & \\
\hline Trachycorystes leopardinus & $\begin{array}{l}\text { Rio São Francisco at Minas Gerais (São } \\
\text { Francisco bioregion) }\end{array}$ & Borodin, 1927a & $\begin{array}{l}\text { Trachelyopterus leopardinus } \\
\text { (Borodin, 1927a) }\end{array}$ & Ferraris-Jr. (2003) & \\
\hline Imparfinis longicauda & $\begin{array}{l}\text { Rio Grande, Franca municipality, São } \\
\text { Paulo State (Upper Paraná bioregion) }\end{array}$ & Borodin, 1927a & $\begin{array}{l}\text { Imparfinis borodini } \\
\text { Mees \& Cala (1989) }\end{array}$ & Mees \& Cala (1989) & \\
\hline Chasmocranus truncatorostris & $\begin{array}{l}\text { Joinville municipality, Santa Catarina } \\
\text { State (Mata Atlântica bioregion) }\end{array}$ & Borodin, 1927a & $\begin{array}{l}\text { Chasmocranus truncatorostris } \\
\text { Borodin (1927a) }\end{array}$ & - & \\
\hline Rhamdella longipinnis & uncertain at São Paulo State & Borodin, 1927a & $\begin{array}{l}\text { Pimelodella longipinnis } \\
\text { (Borodin, 1927a) }\end{array}$ & Bockmann \& Miquelarena (2008) & $\begin{array}{l}\text { now atributed to coastal streams in São } \\
\text { Paulo State, Mata Atlântica bioregion } \\
\text { (this work) }\end{array}$ \\
\hline Caecorhamdella brasiliensis & uncertain at São Paulo State & Borodin, 1927b & $\begin{array}{l}\text { Pimelodella kronei } \\
\text { (Miranda Ribeiro, 1907) }\end{array}$ & Trajano \& Britski (1992) & $\begin{array}{l}\text { known to occur in Rio Ribeira de Iguape } \\
\text { basin (Mata Atântica bioregion) }\end{array}$ \\
\hline Rhinolepis paraguensis & uncertain at Paraguay & Borodin, 1927a & $\begin{array}{l}\text { Otocinclus vittatus } \\
\text { Regan (1904) }\end{array}$ & Isbrücker (2001) & \\
\hline Pimelodus platicirris & $\begin{array}{l}\text { Salto de Pirassununga, Mogi-guaçu River, } \\
\text { São Paulo State (Upper Paraná bioregion) }\end{array}$ & Borodin, 1927c & $\begin{array}{l}\text { Pimelodus platicirris } \\
\text { Borodin (1927c) }\end{array}$ & & \\
\hline
\end{tabular}

Pimelodella longipinnis can be promptly distinguished from all these by the shorter supraoccipital process and dark gray to brown background coloration (vs. supraoccipital process reaching prenuchal plate and light gray to yellowish background coloration).

A thorough revision of Pimelodella material available in Ichthyological collections with collected material from Southeastern Mata Atlântica returned only the aforementioned materials identifiable as P. longipinnis, occurring exclusively in coastal streams of São Paulo State, Brazil. No other Pimelodella species was found syntopically with $P$. longipinnis. These findings lead us to believe that $P$. longipinnis has a restricted distribution, occurring in streams of Santos municipality region. Furthermore, this work brings awareness to a poorly-known species, that occurs in one of the most densely populated regions of Brazil, and which was omitted from other review publications about the region (e.g., Menezes et al., 2007), helping in filling an important gap on Neotropical fish taxonomy.

\section{COMPARATIVE MATERIAL}

In addition to the material listed in Slobodian et al. (2017), the following material was compared in this study:

Pimelodella bahiana, MZUSP 39102, 2 ex, Brazil, Rio

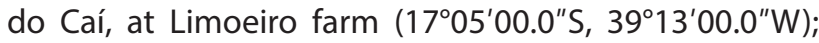
MZUSP 39104, 3 ex, Brazil, Bahia, Rio do Sul, at
Cumuruxatiba-Itamaraju road, before Fazenda Limoeiro (1703'00.0"S, 39²9'00.0"W); MZUSP 63459, 2 ex, Brazil, Bahia, Prado, pier at Rio Jucuruçú bank (17²0'26.0"S, 39 $\left.13^{\prime} 43.0^{\prime \prime} \mathrm{W}\right)$.

Pimelodella brasiliensis, MZUSP 108488, 2 ex, Brazil, Minas Gerais, Teófilo Otoni, Rio Todos os Santos, stream

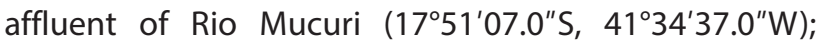
MZUSP 108512, 1 ex, Brazil, Minas Gerais, Teófilo Otoni, Rio Todos os Santos, stream affluent of Rio Mucuri $\left(17^{\circ} 51^{\prime} 49.0^{\prime \prime} \mathrm{S}, 41^{\circ} 33^{\prime} 44.0^{\prime \prime} \mathrm{W}\right)$.

Pimelodella harttii, CAS 75822, 2 ex, Brazil, Minas Geais, rocky mil race at Rio Doce, Rio Doce drainage $\left(20^{\circ} 15^{\prime} 01^{\prime \prime} S\right.$, $\left.42^{\circ} 53^{\prime} 07^{\prime \prime} \mathrm{W}\right)$.

Pimelodella itapicuruensis, MZUSP 88169, 4 ex, Brazil, stream between BR-324 highway and Itaitu, stream afflu-

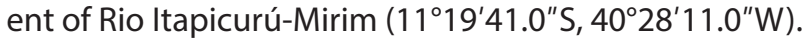

Pimelodella lateristriga, ANSP 174039, 1 ex, Brazil, Rio de Janeiro, stream at Fazenda Conceição on BR-101 highway, approx. $5 \mathrm{~km} \mathrm{~S}$ of the border between Rio de Janeiro/Espírito Santo $\left(21^{\circ} 19^{\prime} 14^{\prime \prime} \mathrm{S}, 41^{\circ} 19^{\prime} 42^{\prime \prime} \mathrm{W}\right)$; ANSP 174041, 2 ex, Brazil, Espírito Santo, Rio Novo do Sul (Rio Noa), on BR-101 highway, just to $S$ of Rio Novo do Sul (2052'33"S, 4057'50"W); LIRP 273, 1 ex, Brazil, Minas Gerais, Joanésia, Rio Santo Antonio, afluente of Rio Doce (19 $\left.10^{\prime} 20^{\prime \prime} \mathrm{S}, 42^{\circ} 40^{\prime} 43^{\prime \prime} \mathrm{W}\right)$; LIRP 7847, 2 ex, Brazil, Espírito Santo, São José do Calçado, Rio Itabapoana, almost 300 m downstream from UHE Rosal's Power Station 
(2057'19.0"S, 4143'01.0"W); MZUSP 41859, 1 ex, Brazil São Paulo, Registro, Rio Quilombo, in Fazenda Dalila

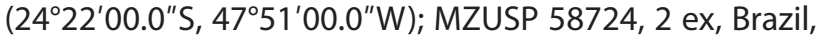
São Paulo, Peruíbe, Rio Itinguçu, stream affluent of Rio Una do Prelado - E.E.J.I. (24²3'59.0"S, 4707'25.0"W); MZUSP 90744, 11 ex, Brazil, Espírito Santo, Iconha, Rio Iconha $\left(20^{\circ} 49^{\prime} 13.0^{\prime \prime} \mathrm{S}, 40^{\circ} 47^{\prime} 46.0^{\prime \prime} \mathrm{W}\right)$; MZUSP 93863, 1 ex, Brazil, Espírito Santo, Pedro Canário, Rio Dourado, affluent of Rio Itaúnas, under the bridge at BR-101 highway (18¹5'09.0"S, 3957'13.0"W); MZUSP 93864, 1 ex, Brazil, Minas Gerais, Nanuque, Córrego do Ene, affluent of Rio Mucuri, at BR-478, towards Teófilo Otoni (1748'30.0"S, 40²4'13.0"W); MZUSP 114867, 1 ex, Brazil, São Paulo, Itanhaém, Rio Branco, at Sítio do Sr. Luís, $6.4 \mathrm{~km}$ after the dam, dirt road left of the main entrance (2401'44.0"S, 46²3'19.6"W); MZUSP 121279, 2 ex Brazil, Rio de Janeiro, Itaguaí, Rio Mazomba, vicinity of Mazomba (22 $\left.{ }^{\circ} 51^{\prime} 37.0^{\prime \prime} \mathrm{S}, 43^{\circ} 52^{\prime} 34.0^{\prime \prime} \mathrm{W}\right)$; MZUSP 121310 , 1 ex, Brazil, Rio de Janeiro, Macaé, Rio Aduelas, affluent of Rio São Pedro, under the bridge at km 157 of BR-101 highway, Rio Macaé basin (22 $\left.15^{\prime} 59.9^{\prime \prime} \mathrm{S}, 41^{\circ} 51^{\prime} 31.0^{\prime \prime} \mathrm{W}\right)$; MZUSP 121461, 9 ex, Brazil, Rio de Janeiro, Conceição de Macabu, Rio Aduelas, stream affluent of Rio São Pedro, in Fazenda Sossego farm, Rio Macaé basin (22 $2^{\circ} 11^{\prime} 56.0^{\prime \prime} \mathrm{S}$, 41 $\left.{ }^{\circ} 50^{\prime} 23.0^{\prime \prime} \mathrm{W}\right) ;$ USNM 100917, 1 ex, Brazil, Rio de Janeiro, Therezopolis, Guapi $\left(22^{\circ} 25^{\prime} 14.7^{\prime \prime} \mathrm{S}, \quad 42^{\circ} 58^{\prime} 20.9^{\prime \prime} \mathrm{W}\right)$; USNM 129923, 3 ex, Brazil, Rio de Janeiro, vicinity of Rio de Janeiro (22 $\left.49^{\prime} 43.5^{\prime \prime} \mathrm{S}, 43^{\circ} 37^{\prime} 34.3^{\prime \prime} \mathrm{W}\right)$; USNM 129925 , 4 ex, Brazil, Rio de Janeiro, vicinity of Rio de Janeiro (22 49'43.5"S, 43³7'34.3"W); USNM 301676, 1 musc., Brazil, Minas Gerais, Rio Mucuri, approx. 26 km SE of town of Nanuque at Fazenda Santa Clara farm, approx. $1 \mathrm{~km}$ downstream from camp site, side channel of main river (1753'47.3"S, 40¹2'22.9"W); USNM 320324, 1 ex, Brazil, Minas Gerais, Ipatinga, Rio Taquaruçu, at BR-381 highway $\left(19^{\circ} 28^{\prime} 57.0^{\prime \prime} \mathrm{S}, 42^{\circ} 32^{\prime} 53.3^{\prime \prime} \mathrm{W}\right)$.

Pimelodella pappenheimi, MZUSP 24584, 4 ex, Brazil, Santa Catarina, Joinville, Rio Cubatão, near Joinville (2610'00.0"S, 4854'00.0"W); MZUSP 28991, 5 ex, Brazil, Santa Catarina, Rio Viralata, affluent of Rio da Prata (264'00.0"S, 4951'00.0"W); MZUSP 41787, 5 ex, 1 c\&s, Brazil, Santa Catarina, Guaruva, Rio Guaruva, under the bridge at BR-101 highway (26일 $\left.18.5^{\prime \prime} \mathrm{S}, 48^{\circ} 51^{\prime} 36.0^{\prime \prime} \mathrm{W}\right)$; USNM 064895, 1 ex, Brazil, Santa Catarina, Joinville, Rio


USNM 279540, 4 ex, Brazil, Santa Catarina, Corupá, stream affluent of Rio Itapocu $\left(26^{\circ} 25^{\prime} 45.7^{\prime \prime} \mathrm{S}, 49^{\circ} 14^{\prime} 13.2^{\prime \prime} \mathrm{W}\right)$.

\section{ACKNOWLEDGMENTS}

The first author is thankful to M. de Pinna for his orientation, insights, and suggestions along her doctorate. We are especially thankful for D.D. Figueiredo, O.T. Oyakawa, M.C.C. de Pinna and J.A.P. Santos and for their help in fieldwork (under SISBIO \#36600, Inventário da ictiofauna da Bacia Hidrográfica do Leste Centro-Sul Paulista); G.T. Vilara for bringing to our attention specimens of $P$. longipinnis from Rio Jurubatuba; H. Britski, A. Datovo, M.
Gianeti, N. Menezes, O.T. Oyakawa, M.C.C. de Pinna and all MZUSP staff for providing the infrastructure needed to make this work possible; and F. Bockmann for allowing us the use of the digital radiography equipment hosted at the Laboratório de Ictiologia de Ribeirão Preto (LIRP), belonging to the Center for Biodiversity Documentation, Department of Biology, FFCLRP/University of São Paulo, Brazil. We are also in debt to A. Esguícero and A. de Lima for examining and providing photos of several LIRP and MZUSP material for species identification; and to Y. Figueiredo for comments regarding Hypostomus brevis distribution. We are grateful to M. Arce, R. Arrindell, M. Britto, P. Buckup, R. Castro, D. Catania, J. Clayton, W. Crampton, K. Hartel, J. Kapp, D. Johnson, C. Lewis, C. Lucena, Z. Lucena, J. Lundberg, J. Maclaine, C. McMahan, S. Mochel, C. Moreira, A. Palandacic, L. Parenti, L. Rapp Py-Daniel, S. Raredon, R. Reis, R. de Ruiter, S. Schaefer, M. Stiassny, K. Swagel, R. Vari, and W. Wosiacki for providing assistance during visits at their institutions, loaning and providing information, photos and $x$-rays of several types and comparative materials of species of Pimelodella. This contribution was also supported by the Diversity and Evolution of Gymnotiformes Project (FAPESP/ Smithsonian process \#2016/19075-9). Research funding for VS was provided by Fundação de Amparo à Pesquisa do Estado de São Paulo (FAPESP, projects \#2013/186234, 2015/26804-4 and 2017/01073-0) and University of Brasília (Edital DPI 02/2021). Research funding for MNLP was provided by Sara E. and Bruce B. Collette Postdoctoral Fellowship in Systematic Ichthyology.

\section{AUTHORS' CONTRIBUTIONS}

VS: Conceptualization, Data curation, Formal Analysis, Funding acquisition, Investigation, Methodology, Project administration, Visualization, Writing - original draft, Writing - review \& editing. BAS: Data curation, Formal Analysis, Investigation, Writing - review \& editing. MNLP: Formal Analysis, Investigation, Validation, Writing - review \& editing. All authors participated in the discussion of the results, reviewed and approved the submitted version of the paper. Also, authors declare no conflict of interest related to this paper.

Funding/Support Agencies: FAPESP/Smithsonian process \#2016/19075-9; VS: FAPESP, projects \#2013/186234, 2015/26804-4 and 2017/01073-0, and UnB Edital DPI 02/2021; MNLP: Sara E. and Bruce B. Collette Postdoctoral Fellowship in Systematic Ichthyology.

\section{REFERENCES}

Agostinho, A.A.; Pelicice, F.M.; Petry, A.C.; Gomes, L.C. \& Júlio-Jr., H.F. 2007. Fish diversity in the upper Paraná River basin: habitats, fisheries, management and conservation. Aquatic Ecosystem Health \& Management, 10(2): 174-186. DOI

Bockmann, F.A. \& Castro, R.M.C. 2010. The blind catfish from the caves of Chapada Diamantina, Bahia, Brazil (Siluriformes: Heptapteridae): 
description, anatomy, phylogenetic relationships, natural history, and biogeography. Neotropical Ichthyology, 8(4): 673-706.

Bockmann, F.A. \& Guazzelli, G.M. 2003. Family Heptapteridae (Heptapterids). In: Reis, R.E.; Kullander, S.0. \& Ferraris-Jr., C.J. (Orgs.). Check List of the Freshwater Fishes of South and Central America. Porto Alegre, EDIPUCRS. p. 406-431.

Bockmann, F.A. \& Miquelarena, A.M. 2008. Anatomy and phylogenetic relationships of a new catfish species from northeastern Argentina with comments on the phylogenetic relationships of the genus Rhamdella Eigenmann \& Eigenmann 1888 (Siluriformes, Heptapteridae). Zootaxa, 1780: $1-54$

Borodin, N.A. 1927a. Some new catfishes from Brazil. American Museum Novitates, 266: 1-7.

Borodin, N.A. 1927b. A new blind catfish from Brazil. American Museum Novitates, 263: 1-5.

Borodin, N.A. 1927c. Pimelodus platicirris, new species, and other notes on Brazilian catfishes. American Museum Novitates, 271: 1-4.

Britski, H.A. \& Garavello, J.C. 1984. Two new southeastern Brazilian genera of Hypoptopomatinae and a redescription of Pseudotocinclus Nichols, 1919 (Ostariophysi, Loricariidae). Papéis Avulsos do Departamento de Zoologia, Secretaria da Agricultura, São Paulo, 35(21): 225-241.

Burgess, W.E. 1989. An atlas of freshwater and marine catfishes. A preliminary survey of the Siluriformes. Neptune, Tropical Fish Hobbyist Publications. $783 p$.

Burgess, W.E. \& Finley, L. 1996. An atlas of freshwater and marine catfishes: Update. Tropical Fish Hobbyist, 45(2): 163-174.

Conde-Saldaña, C.C.; Albornoz-Garzón, J.G.; García-Melo, J.E.; Dergam, J.A. \& Villa-Navarro, F.A. 2019. A new species of Pimelodella Eigenmann \& Eigenmann, 1888 (Siluriformes: Heptapteridae) from the Sierra Nevada de Santa Marta, Colombia. Zootaxa, 4668(4): 562-574.

Cortés-Hernández,M.Á.;DoNascimiento, C.\& Ramírez-Gil, H.2020. Anew species of Pimelodella Eigenmann \& Eigenmann, 1888(Siluriformes: Heptapteridae) from the Orinoco River basin. Zootaxa, 4808(3): 491-506. D01

Dagosta, F.C.; de Pinna, M.; Peres, C.A. \& Tagliacollo, V.A. 2020. Existing protected areas provide a poor safety-net for threatened Amazonian fish species. Aquatic Conservation: Marine and Freshwater Ecosystems, 31(5): 1167-1189. DOI

Eigenmann, C.H. 1917. Pimelodella and Typhlobagrus. Memoirs of the Carnegie Museum, 7: 229-258, pls. 29-35.

Ferraris-Jr., C.J. 2003. Family Auchenipteridae (Driftwood catfishes). In: Reis, R.E.; Kullander, S.0. \& Ferraris-Jr., C.J. (Orgs.). Check list of the freshwater fishes of South and Central America. Porto Alegre, EDIPUCRS. p. 470-482.

Ferraris-Jr., C.J. 2007. Checklist of catfishes, recent and fossil (Osteichthyes: Siluriformes), and catalogue of siluriform primary types. Zootaxa, 1418: $1-628$.

Fowler, H.W. 1951. Os peixes de água doce do Brasil. $3^{3}$ entrega. Arquivos de Zoologia do Estado de São Paulo, 6: 405-628.

Fricke, R.; Eschmeyer, W.N. \& van der Laan, R. (Eds.). 2021. Catalog of fishes: genera, species, references. Available: http://researcharchive.calacademy. org/research/ichthyology/catalog/fishcatmain.asp. Access: 04/01/2021.

Fundação para a Conservação e a Produção Florestal do Estado de São Paulo (Fundação Florestal). 2021. Sobre o Parque Estadual da Serra do Mar. Available: https://www.infraestruturameioambiente.sp.gov.br/pesm/ sobre. Access: 03/02/2021.

Gosline, W.A. 1945. Catálogo dos nematognatos de água-doce da América do sul e central. Boletim do Museu Nacional, Zoologia, 33: 1-138.

Guazzelli, G.M. 1997. Revisão das Espécies de Pimelodella Eigenmann \& Eigenmann, 1888 (Teleostei: Siluriformes: Pimelodidae) dos Sistemas Costeiros do Sul e Sudeste Brasileiro. Master Dissertation. Porto Alegre, Pontifíca Universidade Católica do Rio Grande do Sul,.
International Union for Conservation of Nature and Natural Resources (IUCN), Species Survival Commission (SSC). 2012. IUCN Red List Categories and Criteria: Version 3.1. Available: https://www.iucnredlist.org/resources/ categories-and-criteria. Access: 12/03/2021.

Isbrücker, I.J.H. 1980. Classification and catalogue of the mailed Loricariidae (Pisces, Siluriformes). Verslagen en Technische Gegevens, Instituut voor Taxonomische Zoöogie, Universiteit van Amsterdam, 22: 1-181.

Isbrücker, I.J.H. 2001. Nomenklator der Gattungen und Arten der Harnischwelse, Familie Loricariidae Rafinesque, 1815 (Teleostei, Ostariophysi). DATZ-Sonderheft Harnischwelse, 2: 25-32.

Kubicek, K.M.; Britz, R. \& Conway, K.W. 2019. Ontogeny of the catfish pectoral-fin spine (Teleostei: Siluriformes). Journal of Morphology, 280(3): 339-359.

Leiva C., M. 2005. Revisión taxonómica del género Pimelodella, Eigenmann \& Eigenmann, 1888 (Pisces, Siluriformes: Heptapteridae) de la región transandina de Colombia (Master Dissertation). Bogotá, Universidade Tradicional de Colombia.

Lundberg, J.G. \& Baskin, J.N. 1969. The caudal skeleton of the catfishes, order Siluriformes. American Museum Novitates, 2398: 1-49.

Mees, G.F. 1983. Naked catfishes from French Guiana (Pisces, Nematognathi). Zoologische Mededelingen, 57(5): 43-58.

Mees, G.F. \& Cala, P. 1989. "2 new species of Imparfinis from Northern South-America (Pisces, Nematognathi, Pimelodidae). Proceedings of the Koninklijke Nederlandse Akademie Van Wetenschappen Series c-Biological and Medical Sciences, 92(3): 379-394.

Menezes, N.A.; Weitzman, S.H.; Oyakawa, 0.T.; de Lima, F.C.T.; Castro, R.M.C. \& Weitzman, M.J. 2007. Peixes de água doce da Mata Atlântica: lista preliminar das espécies e comentários sobre conservação de peixes de água doce neotropicais. São Paulo, Museu de Zoologia da Universidade de São Paul0. 407p.

Morgan, L.D. \& Fine, M.L. 2020. Agonistic behavior in juvenile blue catfish Ictalurus furcatus. Journal of Ethology, 38: 29-40. DOI

Netto-Ferreira, A.L. \& Luckenbill, K.R. 2017. The use of ultraviolet light as a non-destructive method for revealing fragments of lost pigmentation in faded alcohol-preserved collection specimens. Proceedings of the Academy of Natural Sciences of Philadelphia, 165: 221-230.

Nichols, J.T. 1919a."Cascudos" brazileiros do genero Plecostomus do Museu Paulista. [Brasilian catfishes of the genus Plecostomus from the Museu Paulista.]. Revista do Museu Paulista, 11: 409-426 [1-8 + 1-8].

Nichols, J.T. 1919b. Um novo genero de cascudos da familia Loricariidae. Revista do Museu Paulista, 11:533-535; 539-540.

Oyakawa, 0.T. \& Menezes, N.A. 2011. Checklist dos peixes de água doce do Estado de São Paulo, Brasil. Biota Neotropica, 11: 19-32. D0I

Pastana, M.; Bockmann, F.A. \& Datovo, A. 2020. The cephalic laterosensory system of Characiformes (Teleostei; 0stariophysi): anatomy and phylogenetic implications. Zoological Journal of the Linnean Society, 189(1): 1-46. DOI

Sabaj, M.H. 2020. Standard symbolic codes for institutional resource collections in herpetology and ichthyology: an online reference (v7.1). American Society of Ichthyologists and Herpetologists, USA. Available: https:// asih.org/sites/default/files/2019-04/Sabaj 2019 ASIH Symbolic Codes v7.1.pdf. Access: 02/01/2021.

Shibatta, 0. 2003. Family Pseudopimelodidae (Bumblebee catfishes, dwarf marbled catfishes). In: Reis, R.E.; Kullander, S.0. \& Ferraris-Jr., C.J. (Orgs.). Check list of the freshwater fishes of South and Central America. Porto Alegre, EDIPUCRS. p. 401-405.

Silva, A.T.; Chagas, R.J.; Santos, A.C.D.A.; Zanata, A.M.; Rodrigues, B.K.; Polaz, C.N.M.; Alves, C.B.M.; Vieira, C.S.; Souza, F.B.; Vieira, F.; Sampaio, F.A.C.; Ferreira, H.; Alves, H.S.R.; Sarmento-Soares, L.M.; Pinho, M.; MartinsPinheiro, R.F.; Lima, S.M.Q.; Campiolo, S. \& Camelier, P. 2020. Freshwater 
fishes of the Bahia State, Northeastern Brazil. Biota Neotropica, 20(4): e20200969. DOI

Silva, G.S.C.; Roxo, F.F.; Melo, B.F.; Ochoa, L.E.; Bockmann, F.A.; Sabaj, M.H; Jerep, F.C.; Foresti, F.; Benine, R.C. \& Oliveira, C. 2021. Evolutionary history of Heptapteridae catfishes using ultraconserved elements (Teleostei, Siluriformes). Zoologica Scripta, 1-12. D0I

Slobodian, V. 2017. Taxonomic revision of Pimelodella Eigenmann \& Eigenmann, 1888 (Siluriformes: Heptapteridae): an integrative proposal to delimit species using a multidisciplinary strategy. Doctoral Thesis. São Paulo, Universidade de São Paulo.

Slobodian, V. \& Pastana, M.N.L. 2018. Description of a new Pimelodella (Siluriformes: Heptapteridae) species with a discussion on the upper pectoral girdle homology of Siluriformes. Journal of fish biology, 93(5): 901-916.

Slobodian, V.; Akama, A. \& Dutra, G.M. 2017. A new species of Pimelodella (Siluriformes: Heptapteridae) from the Guiana Shield, Brazil. Zootaxa, 4338(1): 85-100.

Souza-Shibatta, L.; Pezenti, L.F.; Ferreira, D.G.; Almeida, F.S.; Sofia, S.H. \& Shibatta, 0.A. 2013. Cryptic species of the genus Pimelodella
(Siluriformes: Heptapteridae) from the Miranda River, Paraguay River basin, Pantanal of Mato Grosso do Sul, Central Brazil. Neotropical Ichthyology, 11(1): 101-109.

Taylor, W.R. \& Van Dyke, G.C. 1985. Revised procedures for staining and clearing small fishes and other vertebrates for bone and cartilage study. Cybium, 9(2): 107-119.

Trajano, E. \& Britski, H.A. 1992. Pimelodella kronei (Ribeiro, 1907) e seu sinônimo Caecorhamdella brasiliensis Borodin, 1927: morfologia externa, taxonomia e evolução (Teleostomi, Siluriformes). Boletim de Zoologia, 12: 53-89.

Wilson, J.L. \& Roys, L.L. 1994. Behavioral Interactions in Juvenile Channel Catfish, Ictalurus punctatus. Journal of Applied Aquaculture, 3(3-4): 363-382. DOI

Zawadzki, C.H.; Tencatt, L.F.C. \& Britski, H.A. 2019. Taxonomic revision of Hypostomus albopunctatus (Siluriformes: Loricariidae) reveals a new piece of the Hypostomus jigsaw in the upper Rio Paraná basin. Journal of Fish Biology, 96(1): 230-242. D0I

\section{SUPPLEMENTARY MATERIAL S1}

Video: Subaquatic video of Pimelodella longipinnis school in Rio Quilombo. Conspecific agonistic behavior was observed according to the following categories: head thrust (abrupt swing of head, laterally, against other fish), head wag (series of head thrusts), tail beat (tail thrusts as a means of displacement another fish), tail thrust (powerful lateral swing of the tail), and pectoral brush (pectoral-fin brush along the side of the opponent, either parallel or antiparallel). Available: http://doi.org/10.6084/m9.figshare.14643090.v1. 